\title{
Genetic Analysis of some Crosses for Yield and its Components and Earliness in Pea (Pisum sativum L.)
}

\author{
R. M. Galal", A. G. Mohamed ${ }^{* * *}$ and E. E. M. Ismail ${ }^{* *}$ \\ "Horticulture Department, Faculty of Agriculture, Beni-Suef University, Beni-Suef and \\ ${ }^{* *}$ Vegetable Research Department, Horticulture Research Institute, Agriculture Research \\ Centre, Cairo, Egypt.
}

\begin{abstract}
CROSSES among six pea cultivars viz., Master, Entesar 1, Little Marvel, Entesar 2, Palmoral and Jaguar were achieved. The investigation was carried out at the Sids Horticultural Research Station of the Agricultural Research Center, Beni-Suef Governorate, during the three winter seasons of 2015/2016, 2016/2017 and 2017/2018. Fifteen crosses were made between the parents. The recorded measurements were plant height, number of days to flowering, pod length, pod width, number of seeds/pod, weight of 100-seeds, number of pods/plant and weight of pods/plant. The parents of Entesar2 and Entesar1 showed the best mean performance followed by Jaguar for the most studied traits. The cross combinations of Entesar1 x Entesar2, Entesar1 x Master and Entesar1 x Little Marvel showed the best mean performance for the most studied traits. The $\mathrm{F}_{1}$ hybrids of Master $\times$ Little Marvel, Little Marvel $\times$ Master, Entesar 1 $\mathrm{x}$ Entesar2, Entesar1 $\times$ Little Marvel, Little Marvel $\times$ Entesar1 and Master $\times$ Palmoral exhibited a heterosis for the most traits. The obtained results of mean performance, heterosis and potance ratio demonstrated that the hybrids of Master $\times$ Little Marvel, Little Marvel $\times$ Master, Entesar 1 $\mathrm{x}$ Entesar2 and Entesar $1 \times$ Little Marvel are the best hybrids. Plant height, number of days to flowering, pod width, pod weight and number of pods/plant were positively and significantly correlated with pod yield per plant, which are of great importance as selection criteria for yield improvement of pea.These findings can be utilized further in selection programs to enhance the yield potential of pea genotypes.
\end{abstract}

Keywords: Pisum sativum, Heterosis, Potance ratio, Correlation.

\section{Introduction}

Pea (Pisum sativum L.) is one of the most important vegetable crops for both local consumption and exportation. Therefore, it is of interest to increase its yield's quality and quantity to fulfill the exportable and locality demands. This can be attained through the intensive efforts by plant breeders. Pea breeders have a great consent on the notion of existence of potential for enhanced productivity in this crop (Kumaran et al., 1995). Enhancing yield of peas, indeed, is one of the major objectives (Simakov, 1989), regardless of the initial purpose of any breeding program. So, when there are no differences, the breeders should create this variability through various methods of breeding.

Recently there are intensive efforts for improvement of pea productivity in Egypt through breeding procedures depending mainly on the presence of genetic differences that permits effective selection. Hybridization is considered an effective factor for inducing variability, and this method is used widely to improve self-pollinating crops plants and to produce new lines and developing quantitative traits in pea. The genetic performance of pea was studied under Upper Egypt conditions in many studies which demonstrated that about $78 \%$ of phenotypic variances were due to genetics and the results revealed that the parent Master could be used as progenitors for studying traits in genetic improvement by means of selection in the segregating generations (Zayed, 1998, Zayed et al., 1999 a\&b, El-Dakkak, 2005, El-Dakkak et al., 2014 and Baghdady et al., 2015). Earliness and high yield potential became a main requirement for accepting any new pea cultivar. Master cultivar could be used in improving pea productivity (Zayed et al., 2005, El-Dakkak et al., 2009 and Abd El-Atty et al., 2010). Agronomic characters of pea show significant differences in heterosis (Lejeune-Henaut et al., 1992, Sarawat et al., 1994, Sharma et al., 1999 and Ceyhan 2003). Lejeune-Henaut et al. (1992) found that yield 
average heterosis over mid-parent is $40 \%$ and average heterosis over the better parent is $22 \%$. Heterosis for yield components was significant only for the number of pods/plant and the number of sseds/pod on the branches. Sarawat et al. (1994) found that the average level of heterosis over the mid-parent was positive for all traits except for the seeds per pod and seed weight. Also, they reported that significant positively correlation between grain yield with pods per plant and hundred seed weight in pea. Zayed and Faris (1998) indicated that heterosis over both mid-parents and high parent was maximum for weight and number of pods per plant in the $\mathrm{F}_{1}$ cross over the two study locations, while, low heterosis was noticed in all crosses for pod length and width. Nosser (2002) found that heterosis over the taller parent was ranged from $0.98 \%$ to $83.28 \%$. All the studied crosses exhibited positive heterosis over better parent ranging from $13.59 \%$ to $36.59 \%$. Ceyhan and Avci (2005) found that grain yield was highly significant heterosis $83.2 \%$ over mid-parent and $66.8 \%$ over better parent. Hamed (2005) found that positive heterosis over the better parent for plant length was ranged from $6.44 \%$ to $104.21 \%$. Zayed et al. (2005) reported that the maximum significant heterosis in desirable direction was recorded for fresh pod yield/feddan followed by earliness, number of seeds/pod and fresh pod yield/feddan. Pandey et al. (2006) found that average heterosis was observed for plant height, pods per plant, pod length, seeds per pod and pod yield. Eleven crosses exhibited significant positive heterosis over best parent for pod yield. Ceyhan et al. (2008) reported that heterosis was found to be significant for seed yield and its components. El-Dakkak et al. (2009) indicated that heterotic effect was pronounced for all studied traits except flowering and the expression varied with crosses and traits. Hasan et al. (2010) found that the maximum significant mid parent heterosis in desirable direction was recorded for stem length followed by pod yield/plant, seed weight of 10pods, seed yield/plant and number of pods/plant. Muhammed et al. (2009) found that grain yield had significant correlation with pods per plant. Nassef and El-Rawy (2013) found a significant and positive correlation between yield/plant and pods number/plant. El-Shaieny and Ibrahim (2017) found that the genetic variation was high for number of days to flowering and green seed yield/plant. El-Dakkak and Hussein (2009) found that potence ratio that measured the average of dominance confirmed the partial dominance for

Egypt. J. Hort. Vol. 46, No. 1 (2019) earliness and over dominance for the remainder growth traits. El-Murabaa et al. (1988b) found significant positive correlation between total green yield and each of pod length, pod weight and seed weight of 10 pods. Abdou et al. (1999) found that pod yield could be efficiently selected through pod length and 100-seed weight. Togay et al. (2008) found that significant and positive phenotypic correlations were found for seed yield with pods per plant. Hasan et al. (2010) found that stem length, number of pods per plant and pod yield could be used as a selection index for increasing seed yield. Ghobary (2010) found that positive significant as association of pods per plant with seed yield per plant. In case of pod length, a positive significant correlation existed between number of seeds per pod, concerning seed yield per plant it had positive significant correlation. Positive significant association of 100- seed weight with seed yield per plant. Nassef and El-Rawy (2013) found a significant and positive correlation between yield/plant and pods number/plant. Kumar et al. (2013) stated that correlation analysis revealed that seed yield per plant recorded high significant and positive association with number of pods per plant.

The main objective of present investigation was estimating the degree of heterosis for yield and yield components for different cross combinations, finding the combination having highly yield potential to be used in further breeding program, and estimating the potance tatio and correlation for studied traits.

\section{Materials and Methods}

This investigation was carried out at the Sids Horticultural Research Station of the Horticultural Research Institute, Agricultural Research Center, Beni-Suef Governorate, Egypt, during the three winter seasons of 2015/2016, $2016 / 2017$ and $2017 / 2018$. The soil was clay loam. Six different pea cultivars (Pisum sativum L.) represented a wide range of variability in their economic traits were used in this study. These cultivars were Master (P1), Entesar 1 (P2) Little Marvel (P3), Entesar 2 (P4), Palmoral (P5) and Jaguar (P6). Master, Entesar 1 and Little Marvel cultivars were early in flowering and used as females for studying the earliness in pea. The cultivars were planted on $15^{\text {th }}$ October 2015 each alone under open field conditions in one season to insure the purity of each parent before crossing. Cultivars were planted on two dates $\left(10^{\text {th }}\right.$ and $30^{\text {st }}$ October in 2016) and fifteen crosses were made 
at flowering stage as follows, Master x Entesar 1, Master x Little Marvel, Master x Entesar 2, Master x Palmoral, Master x Jaguar, Entesar 1 x Master, Entesar 1 x Little Marvel, Entesar 1 x Entesar 2, Entesar 1 x Palmoral, Entesar 1 x Jaguar, Little Marvel x Master, Little Marvel x Entesar 1, Little Marvel x Entesar 2, Little Marvel $x$ Palmoral, Little Marvel x Jaguar. Flowers of the female parents were emasculated one day prior to anthesis and the pollen grains from the completely opened flowers of the male parents were applied on the stigma of the female parents to produce the $F_{1}$ seeds. Seeds of parents and $F_{1}$ populations for each cross were sown on $17^{\text {th }}$ October 2017 in a randomized complete block design with three replicates. The parents were represented by three rows, while the $F_{1}$ populations were represented by single row per block. Each row was $5 \mathrm{~m}$ long and $0.7 \mathrm{~m}$ wide. Individual seeds were sown $20 \mathrm{~cm}$ apart. All cultural practices were applied according to the recommendations of the Egyptian Ministry of Agriculture.

Data were recorded at the harvesting time on individual plants from the parents and $\mathrm{F}_{1}$ progeny in each cross for the following characters: plant height, number of days to flowering which was measured as the number of the days from the sowing until the first flower anthesis, pod length, width and weight which were estimated as the mean of five pods/plant, number of seeds/pod which was estimated as the mean number of seeds per five pods/plant, number of pods/plant, 100 -green seed weight which was calculated by dividing the seeds weight of five pods by their number and weight of pods/plant.

The statistical analysis was done by using the computer program MSTAT-C. Analysis of variance for the randomized complete block design was carried out according to Snedecor and Cochran, 1982. Means for the parents and $F_{1}$ generation were compared using Duncan's multiple range test Duncan, 1955.

Two types of heterosis [relative heterosis $(\mathrm{MPH})$ and heterobeltiosis (BPH)] were estimated and expressed as percentages (Sinha and Khanna, 1975).

Mid-parent heterosis $(\mathrm{MPH} \%)=\left(\mathrm{F}_{1}-\mathrm{MP}\right) / \mathrm{MP}$ $\times 100$

Better parent heterosis $(\mathrm{BPH} \%)=\left(\mathrm{F}_{1}-\mathrm{BP}\right) / \mathrm{BP}$ $\times 100$

The ' $t$ ' test was manifested to determine whether $F_{1}$ hybrid means were statistically different from mid parent and better parent means as follows (Wynne et al., 1970 ):

$$
\begin{aligned}
& \text { " } t \text { " for } \mathrm{MPH}=\left(\mathrm{F}_{1}-\mathrm{MP}\right) / \sqrt{ } 3 \backslash 8(\mathrm{EMS}) \text {. } \\
& \text { " } \mathrm{t} \text { " for } \mathrm{BPH}=\left(\mathrm{F}_{1}-\mathrm{BP}\right) / \sqrt{ } 1 \backslash 2(\mathrm{EMS}) \text {. }
\end{aligned}
$$

Where: $\mathrm{F}_{1}=$ The mean of the $\mathrm{F}_{1}$ cross, MP $=$ The mid parent for the cross, $\mathrm{BP}=$ The better parent values for the cross and EMS = Error mean square.

Potence ratio was calculated according to Smith (1952) to determine the degree dominance as follows:

$$
\mathrm{P}=\left(\mathrm{F}_{1}-\mathrm{MP}\right) / 0.5(\mathrm{P} 2-\mathrm{P} 1) .
$$

Where P: relative potence of gene set, $\mathrm{F}_{1}$ : first generation mean, P1: the mean of lower parent, P2: the mean of higher parent and MP: mid-parents' value $=(\mathrm{P} 1+\mathrm{P} 2) \backslash 2$. Complete dominance was indicated when $\mathrm{P}= \pm 1$; while partial dominance was indicated when " $\mathrm{P}$ " is between $(-1$ and +1$)$, except the value zero which indicates absence of dominance. Overdominance was considered when potence ratio exceeds \pm 1 . The positive and negative signs indicate the direction of dominance of either parent.

The simple correlation coefficients were calculated following Singh and Chaudhary (1985).

\section{Results and Discussion}

\section{Mean performance}

Mean performance of six parents and fifteen hybrids in $F_{1}$ generation for all studied traits are presented in Table 1. Palmoral (P5) cultivar was the best for plant height, while Master (P1) cultivar was the best for earliness in flowering. Entesar 2 (P4) and Entesar 1(P2) cultivars gave the tallest pod and the widthest pod. Entesar 1(P2) gave the highest number of seeds/pod and the heaviest 100-green seed weight, while Entesar 2 (P4) gave the significant highest values of pod weight, number of pods/plant and weight of pods/plant. These results agree with those obtained by Zayed et al. (2005); El-Dakkak et al. (2009) and Abd ElAtty et al. (2010). Considerable variations were obtained among all $\mathrm{F}_{1}$ hybrids for all studied traits. Little Marvel x Palmoral cross was the best for plant height as compared to the other crosses in $F_{1}$ generation. Meanwhile, Entesar 1 x Little Marvel and Little Marvel x Master crosses exhibited earliness in number of days to flowering as compared with the other crosses in $\mathrm{F}_{1}$ generation. In addition, Entesar $1 \mathrm{x}$ Little Marvel, Entesar $1 \mathrm{x}$ Master and Entesar $1 \times$ Entesar 2 crosses were the highest for pod length in $\mathrm{F}_{1}$ generation. Entesar $1 \mathrm{x}$ Entesar 2 cross was the best for pod width and pod weight, 100-green seed weight and weight of pods/ plant. Entesar 1x Little Marvel, Entesar 1 x Master, Entesar 1 x Entesar 2, Entesar 1 x Palmoral and Entesar 1x Jaguar crosses were the best for number 
TABLE 1. Mean performance of pea parents and crosses in $F_{1}$ generation

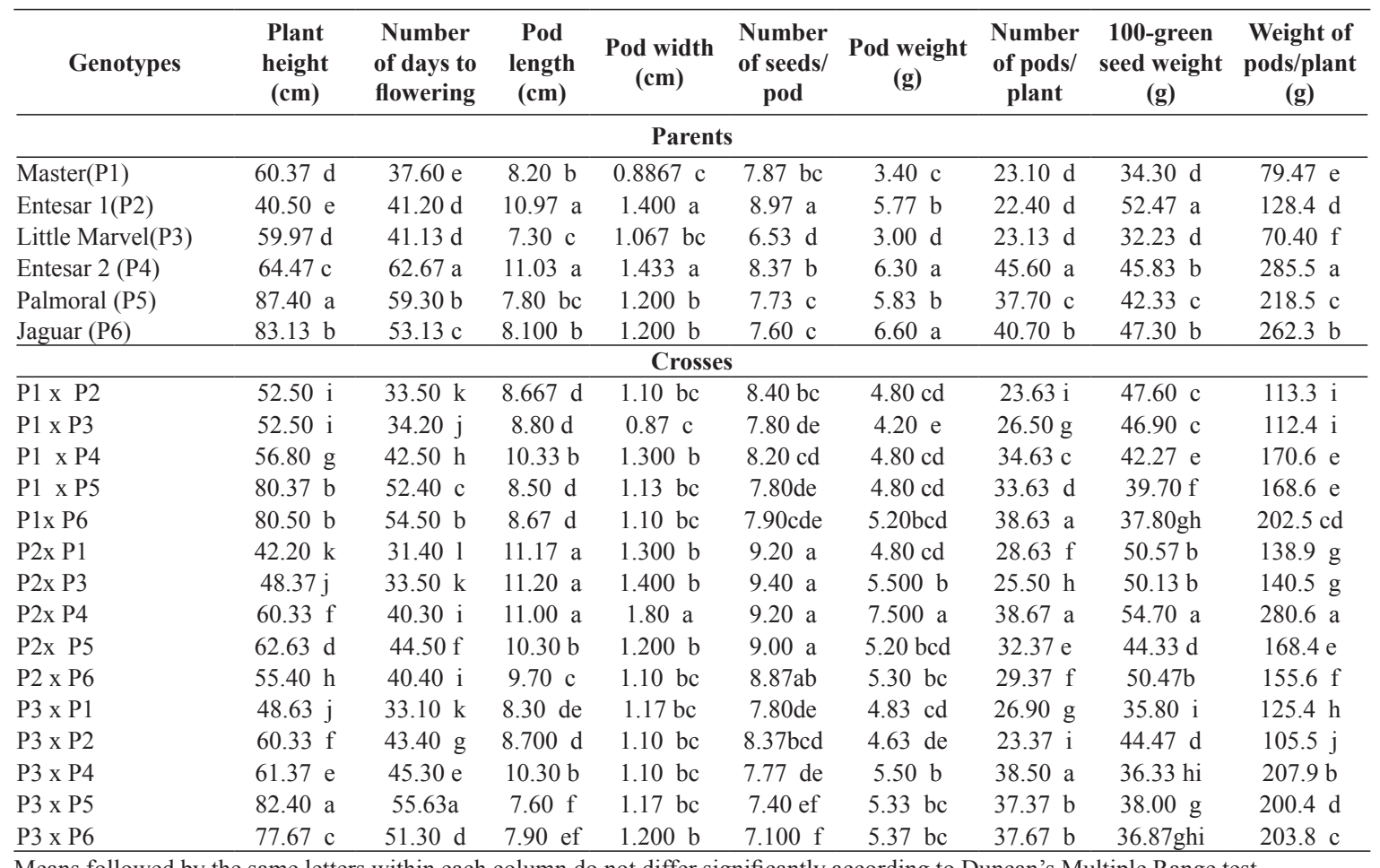

Means followed by the same letters within each column do not differ significantly according to Duncan's Multiple Range test at the $5 \%$ level of probability.

of seeds/pod. In addition, Entesar 1x Entesar 2, Master x Jaguar and Little Marvel x Entesar 2 crosses were the best hybrids for number of pods/ plant and weight of pods/plant. These results agree with those obtained by El-Murabaa et al. (1988a), Zayed et al. (2005), El-Dakkak et al. (2009) and Abd El-Atty et al. (2010).

\section{Heterosis}

Heterosis percentages over mid-parent and better parent for all studied traits are given in Table 2 and 3. The results indicated that the expression of heterosis varied with the investigated crosses and traits. Results revealed that heterosis for plant height varied from -19.2 to $20.1 \%$ and -33.3 to $0.6 \%$ over the mid-parent and better parent, respectively. Results also showed that 7 out of 15 crosses exhibited highly significant positive heterosis values over the mid-parent, indicating partial dominance for plant height, while 8 crosses exhibited highly significant negative heterosis values over the mid-parent. On the other hand, no cross showed highly significant positive values of heterosis over the better parent, while 14 crosses exhibited highly significant negative heterosis values over the better parent. Heterosis for number of days to flowering varied from -22.4 to $20.1 \%$ and -18.4 to $44.9 \%$ over the mid-parent and better parent, respectively. The results showed that 5 crosses out of 15 crosses exhibited highly significant positive heterosis over the mid-parent and 8 crosses out of 15 showed significant and highly significant positive values of heterosis over the better parent, while 10 and 6 crosses exhibited highly significant negative heterosis values over the mid-parent and better parent for number of days to flowering. Heterosis for pod length varied from -9.2 to $23.1 \%$ and -20.4 to $7.3 \%$ over the mid-parents and better parent heterosis, respectively. The results showed that 9 crosses out of 15 exhibited significant and highly significant positive heterosis over the mid-parent. On the other hand, no cross showed highly significant positive values of heterosis over the better parent, while 1 and 2 crosses exhibited significant and highly significant negative heterosis values over the mid-parents and better parent, respectively. Heterosis for pod width varied from -15.3 to 16.7 $\%$ and -26.6 to $20.0 \%$ over the mid-parents and better parent, respectively. The results showed that 2 crosses out of 15 studied crosses exhibited significant and highly significant positive heterosis over the mid parent, indicating over-dominance for wider pod, while 2 crosses exhibited highly 


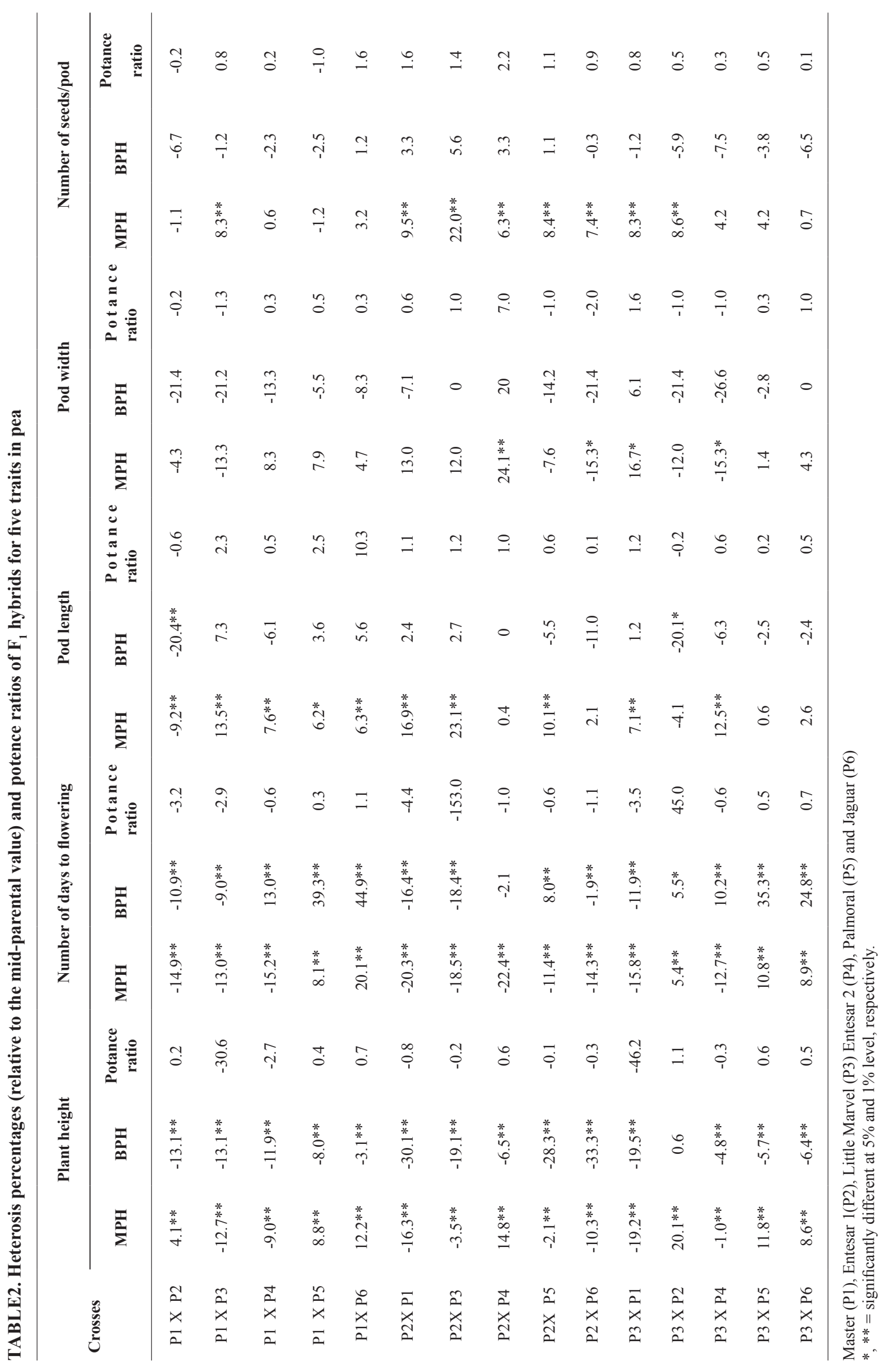

Egypt. J. Hort. Vol. 46, No. 1 (2019) 
significant negative heterosis values over the mid- parents. For number of seeds/pod varied from -1.2 to $22.0 \%$ and -7.5 to $5.6 \%$ over the mid-parents and better parent, respectively. The results showed that 8 crosses exhibited highly significant positive heterosis over the mid-parent, indicating over-dominance for number of seeds/ pod. For pod weight varied from -14.5 to 51.0 $\%$ and -23.8 to $42.1 \%$ over the mid-parents and better parent, respectively. The results showed that 7 crosses out of 15 exhibited significant and highly significant positive heterosis over the midparents, indicating over-dominance, while 1 and 2 crosses exhibited significant and highly significant negative heterosis values over the mid-parents and better parent, respectively. Heterosis for pod width varied from -15.3 to $16.7 \%$ and -26.6 to $20.0 \%$ over the mid-parents and better parent, respectively. The results showed that 2 crosses out of 15 studied crosses exhibited significant and highly significant positive heterosis over the mid parent, indicating over-dominance for wider pod, while 2 crosses exhibited highly significant negative heterosis values over the mid- parents. For number of seeds/pod varied from -1.2 to $22.0 \%$ and -7.5 to $5.6 \%$ over the mid-parents and better parent, respectively. The results showed that 8 crosses exhibited highly significant positive heterosis over the mid-parent, indicating over-dominance for number of seeds/

TABLE 3. Heterosis percentages (relative to the mid-parental value) and potence ratios of F1 hybrids for four traits in pea

\begin{tabular}{|c|c|c|c|c|c|c|c|c|c|c|c|c|}
\hline Crosses & \multicolumn{3}{|c|}{ Pod weight } & \multicolumn{3}{|c|}{ Number of pods/plant } & \multicolumn{3}{|c|}{ 100-green seed weight } & \multicolumn{3}{|c|}{ Weight of pods/plant } \\
\hline $\mathrm{P} 1 \times \mathrm{P} 2$ & 4.3 & -17.2 & 0.1 & $3.4 * *$ & 2.3 & 1.7 & $9.6^{* *}$ & $-9.3 * *$ & 0.4 & $8.9^{* *}$ & $-11.7^{* *}$ & 0.4 \\
\hline $\mathrm{P} 1 \times \mathrm{P} 3$ & $31.2 * *$ & 23.5 & -5.0 & $14.2 * *$ & $14.7^{* *}$ & 33.0 & $41.0 * *$ & $36.7 * *$ & 13.0 & $49.9 * *$ & $41.3^{* *}$ & 8.2 \\
\hline $\mathrm{P} 1 \times \mathrm{P} 4$ & -1.0 & $-23.8^{*}$ & -0.1 & 0.5 & $-24.0 * *$ & 0.1 & $5.5^{* *}$ & $-7.7 * *$ & 0.4 & $-6.5^{* *}$ & $-40.2 * *$ & -0.1 \\
\hline $\mathrm{P} 1 \times \mathrm{P} 5$ & 5.4 & -15.7 & 0.2 & $10.2 * *$ & $-10.7 * *$ & 0.4 & $3.6^{* *}$ & $-6.1 * *$ & 0.4 & $13.1 * *$ & $-22.8 * *$ & 0.3 \\
\hline P2x P1 & 4.3 & -17.2 & 0.2 & $25.4^{* *}$ & $23.9 * *$ & 12.8 & $16.5^{* *}$ & $-3.6 * *$ & 0.8 & $33.0 * *$ & $8.2 * *$ & 1.4 \\
\hline P2x P3 & $25.0 * *$ & -5.1 & 0.8 & $12.1 * *$ & $10.3 *$ & 7.8 & $18.3 * *$ & $-4.5 * *$ & -0.8 & $41.3 * *$ & $9.4 * *$ & 1.4 \\
\hline $\mathrm{P} 2 \mathrm{x} \mathrm{P} 4$ & $23.9 * *$ & 19.0 & 5.8 & $13.7 * *$ & $-15.2 * *$ & 0.4 & $11.2 * *$ & 4.1 & -1.7 & $35.6 * *$ & $-1.7 * *$ & 0.9 \\
\hline $\mathrm{P} 2 \mathrm{x}$ P5 & $-7.8 *$ & -8.6 & -9.0 & $7.7 * *$ & $-14.1 * *$ & 0.3 & $-6.4 * *$ & $-15.5 * *$ & 0.6 & $-2.9 * *$ & $-22.9 * *$ & -0.1 \\
\hline $\mathrm{P} 2 \times \mathrm{P} 6$ & $-14.5 * *$ & -19.6 & -2.2 & $-6.9 * *$ & $-27.8 * *$ & -0.2 & 1.1 & $-3.8 * *$ & -0.2 & $-20.3 * *$ & $-40.6^{* *}$ & -0.5 \\
\hline P3 x P5 & $22.6^{* *}$ & -6.4 & 0.7 & $22.9 * *$ & -0.9 & 1.0 & 2.0 & $-10.1 * *$ & 0.1 & $38.7 * *$ & $-8.2 * *$ & 0.8 \\
\hline P3 x P6 & $11.8 * *$ & -18.6 & 0.3 & $18.1^{* *}$ & $-7.4 * *$ & 0.6 & $-7.2 * *$ & $-22.1 * *$ & -0.3 & $22.4 * *$ & $-22.3 * *$ & 0.4 \\
\hline
\end{tabular}

Master (P1), Entesar 1(P2), Little Marvel (P3), Entesar 2(P4), Palmoral (P5) and Jagur (P6).

$*, * *=$ significantlydifferent at $5 \%$ and $1 \%$ level, respectively.

Egypt. J. Hort. Vol. 46, No. 1 (2019) 
pod. For pod weight varied from -14.5 to 51.0 $\%$ and -23.8 to $42.1 \%$ over the mid-parents and better parent, respectively. The results showed that 7 crosses out of 15 exhibited significant and highly significant positive heterosis over the mid-parents, indicating over-dominance, while 1 and 2 crosses exhibited significant and highly significant negative heterosis values over the midparent and better parent. For pod number/plant varied from -6.9 to $25.4 \%$ and -27.8 to $23.9 \%$ over the mid-parent and better parent heterosis are considered. The results showed that 13 and 4 crosses out of 15 exhibited significant and highly significant positive heterosis over the mid-parent and better parent, indicating over-dominance for number of pods/plant. For 100-green seed weight varied from -7.3 to $41.0 \%$ and -22.1 to $36.7 \%$ over the mid-parent and better parent heterosis. The results showed that 1 and 9 crosses out of 15 exhibited highly significant positive heterosis over the mid-parent and over better parent, indicating over-dominance for high 100-green seed weight. Concerning weight of pods/plant, the results revealed that heterosis varied from -20.3 to 67.3 $\%$ and -40.6 to $57.7 \%$ over the mid-parents and better parent heterosis, respectively. The results showed that 4 and 12 crosses out of 15 exhibited highly significant positive heterosis over the mid-parents and over better parent, indicating over-dominance for weight of pods/plant, while 3 and 11 crosses exhibited highly significant negative heterosis values over the mid- parents and better parent. Generally, the crosses Master x Little Marvel, Little Marvel x Master, Entesar 1x Entesar 2, Entesar 1 x Little Marvel, Little Marvel $\mathrm{x}$ Entesar 1 and Master $\mathrm{x}$ Jaguar were the best crosses for the most traits. Similar results have been reported by Lejeune-Henaut et al. (1992), Sarawat et al. (1994), Ceyhan (2003), Abd ElAtty et al. (2010), Hasan et al. (2010) and Brar et al. (2012). Katiyar (1994) revealed significant heterobeltiosis for days to 50 percent flowering. El-Dakkak and Hussein (2009) found that the maximum significant mid-parents and better parent heterosis in desirable direction $(79.6 \%$ and $45.4 \%$ respectively) were recorded for seed yield/ feddan.

\section{Potence ratio}

The estimated values of potence ratio (Tables 2 and 3 ) in most $F_{1}$ crosses showed that the estimated potence ratios had a positive nature for number of pods/plant, weight of pods/plant, pod length, number of seeds/pod, pod weight, 100seed weight, pod width and plant height. These results reflected various degrees of dominance; i.e., complete dominance, partial-dominance and over-dominance which involved in the inheritance of these characters. On the contrary, the estimated values of potence ratios in most $\mathrm{F}_{1}$ hybrids for number of days to flowering were negative. Potence ratios had positive nature for number of pods per plant and ranged from 0.1 to 37.0 follwed by pods weight per plant, pod weight and number of seeds per pod. Master $\mathrm{x}$ Little Marvel, Little Marvel x Master, Entesar 1 x Entesar 2, Entesar $1 \mathrm{x}$ Master and Entesar 1x Little Marvel $F_{1}$ hybrids exhibited over dominance for the most traits. While, Master $\times$ Entesar 2, Little Marvel $\times$ Entesar 2, Little Marvel $\times$ Palmoral and Little Marvel $\times$ Jaguar $\mathrm{F}_{1}$ hybrids exhibited partial dominance for the most traits. Concerning number of days to flowering, the results showed that over-dominance effects were reflected on the performances of $8 \mathrm{~F}$ hybrids. These results agreed with that obtained by Zayed (1998), Zayed

TABLE 4. Correlation cofficients among different pairs of characters for $F_{1}$ generation

\begin{tabular}{|c|c|c|c|c|c|c|c|c|}
\hline Traits & $\begin{array}{l}\text { Plant } \\
\text { height }\end{array}$ & $\begin{array}{l}\text { Number } \\
\text { of days } \\
\text { to } \\
\text { flowerin }\end{array}$ & $\begin{array}{l}\text { Pod } \\
\text { length }\end{array}$ & $\begin{array}{l}\text { Pod } \\
\text { width }\end{array}$ & $\begin{array}{l}\text { Number } \\
\text { of seeds/ } \\
\text { pod }\end{array}$ & $\begin{array}{l}\text { Pod } \\
\text { weight }\end{array}$ & $\begin{array}{l}\text { Number } \\
\text { of pods/ } \\
\text { plant }\end{array}$ & $\begin{array}{l}\text { 100-green } \\
\text { seed } \\
\text { weight }\end{array}$ \\
\hline plant height & 1 & & & & & & & \\
\hline Number of days to flowering & $0.971 * *$ & 1 & & & & & & \\
\hline Pod length & $-0.575^{* *}$ & $-0.473 * *$ & 1 & & & & & \\
\hline Pod width & -0.101 & -0.098 & $0.486^{* *}$ & 1 & & & & \\
\hline Number of seeds/pod & $-0.577 * *$ & $-0.530 * *$ & $0.724 * *$ & $0.421 * *$ & 1 & & & \\
\hline Pod weight & 0.129 & 0.125 & $0.359 *$ & $0.625 * *$ & $0.294 *$ & 1 & & \\
\hline Number of pods/plant & $0.677 * *$ & $0.724 * *$ & -0.023 & 0.255 & $-0.334 *$ & $0.508^{* *}$ & 1 & \\
\hline 100 -green seed & $0.571 * *$ & $-0.589 * *$ & $0.619 * *$ & $0.389 * *$ & $0.780 * *$ & $0.298 *$ & $-0.386 * *$ & 1 \\
\hline Pods weight/plant & $0.510 * *$ & $0.532 * *$ & 0.168 & $0.524 * *$ & -0.057 & $0.789 * *$ & $0.904 * *$ & -0.063 \\
\hline
\end{tabular}

*and ** indicate significant at 0.05 and 0.01 probability levels, respectively 
and Faris (1998), Zayed et al., (2005) and ElDakkak and Hussein (2009), and these authers found that measured the average of dominance confirmed the partial dominance for flowering dates. Overdominance was detected for remainder for stem length and number of branches.

\section{Phenotypic correlation among the studied traits}

Phenotypic correlation coefficients for all comparisons among the studied traits are presented in Table 4 which show that pod weight/plant was positively and significantly correlated with each of plant height, number of days to flowering, pod width, pod weight and number of pods/plant. A Significant positive correlation was observed between plant height, number of days to flowerin, pod width, pod weight and number of pods/plant with pods weight/plant.Significant positive correlation was detected between plant height with number of days to flowering, number of pods/plant and pods weight/plant. Also, significant positive correlation was observed between number of days to flowering with number of pods/plant and pods weight/plant. A significant positive correlation was detected between pod length with pod width, number of seeds/pod, 100seed weight and pods weight/plant. Also, significant positive correlation was observed between pod width with number of seeds/pod, pod weight, 100-seed weight and pods weight/ plant. Significant positive correlation was observed between number of seeds/pod with pod weight and 100-seed weight. Significant positive correlation was observed between pod weight with number of pods/plant,100seed weight and pods weight/plant. In contrast, significant negative correlations were observed between plant height and number of days to flowering with pod length, number of seeds/ pod and100-seed weight, and between number of seeds/pod with number of pods/plant. Also, significant negative correlations were observed for number of pods/plant and pods weight/ plant with 100-seed weight. Correlation studies generally indicated that plant height, number of days to flowering, pod width, pod weight and number of pods/plant were positively and significantly correlated with pods weight per plant, indicating the importance of these traits as selection criteria. These results are in harmony with those previously obtained by ElMurabaa et al. (1988b), Sarawat et al. (1994), Abdou et al. (1999), Chaudhary and Sharma (2003), Kumar \& Jain (2003), Kumar \& Sharma (2006), Nawab et al. (2008), Togay et al. (2008), Muhammed et al. (2009), Ghobary (2010), Hasan et al. (2010) and Nassef \& ElRawy (2013) who found that yield per plant showed positive correlation with pods per plant Egypt. J. Hort. Vol. 46, No. 1 (2019) and pod length. Kumar et al. (2013) observed that seed yield per plant highly significant and positive association with number of pods plant, and seed pod had significant and positive association with 100 seed weight. Kannoj (2016) found that correlation coefficient analysis of seed yield/plant was recorded highly significant and positive with, number of pods/plant, pod length and number of seeds/pod which indicated that effective improvement in field pea yield through these components could be achieved. Also, Shukla (2015) found that correlation coefficient of seed yield per plant was recorded highly significant and positive with number of pods per plant and hundred seed weight which indicated that effective improvement in field pea yield through these components could be achieved.

\section{Conclusion}

From the presented data in the current-study, it could be concluded that Entesar 2 and Entesar 1 showed the best mean performance followed by Jaguar for the most studied traits. Generally and based on mean performance, heterosis and potence ratio results illustrated that the hybrids of Master $\times$ Little Marvel, Little Marvel $\times$ Master, Entesar 1x Entesar 2 and Entesar $1 \times$ Little Marvel are the best hybrids. The characters plant height, number of days to flowering, pod width, pod weight and number of pods/plant were positively and significantly correlated with pods weight per plant, which are they of great importance selecting criteria for yield improvement in pea.

\section{Acknowledgment:}

No acknowledgments were declared

Funding statements:

No funding was provided

Conflicts of interest:

No conflicts were declared

\section{$\underline{\text { References }}$}

Abd El-Atty, Y.Y., Zayed, G.A, Abd El-Monem, M.N. and Abd El-Lah, H.S. (2010) Gene effects and combining ability for some important traits of pea. Minia $2^{\text {nd }}$ conf. Agric. Environ. Sci., 161-169.

Abdou, A.A., Mohamed, M.F. and Kandeel, N.M. (1999) Breeding implications on cultivar-selection in garden pea (Pisum sativum L.) towards enhancing earliness and pod-yield. Assiut J. Agri. Sci., 30 (3), 117-132.

Baghdady, G.A., Zayed, G.A., Ali, H.A.O. and Damarany, A.M. (2015) Pedigree selection for earliness and yield in pea (Pisum sativum L.). Egypt. J. Appl. Sci, 30 (1), 24-33. 
Brar, P.S., Dhall, R.K. and Dinesh (2012) Heterosis and combining ability in garden pea (Pisum sativumL.) for yield and its contributing traits. Vegetable Sci., 39 (1),51-54.

Ceyhan, E. (2003) Determination of some agricultural characters and their heredity through line $\mathrm{x}$ tester method in pea parents and crosses. Selcuk Univ., Graduate School Nat. Appl. Sci., p. 103.

Ceyhan, E. and Avci, M.A. (2005) Combining ability and heterosis for grain yield and components in pea (Pisum sativum L.). Pakestan J. of Biological Sci., 8(10), 1447-1452.

Ceyhan, E., Avci, M.A. and Karada, S. (2008) Line $\mathrm{X}$ tester analysis in pea (Pisum sativum L.): Identification of superior parents for seed yield and itscomponents. African J. Biotechnology, 7 (16), 2810-2817.

Chaudhary, D.K. and Sharma, R.R. (2003) Genetic variability, correlation and path analysis for green pod yield and itscomponents in garden pea. Indian J. Hort., 60 (3), 251-256.

Duncan, D.B. (1955) Multiple range and multiple F test. Biometrics, 11, 1-42.

El-Dakkak, A.A.A. (2005) Estimation of the components of the genetic variation using triple test cross analysis in peas (Pisum sativum L.) under Upper Egypt conditions. Ph.D. Thesis, Assiut Univ. 146 p.

El-Dakkak, A.A.A. and Hussein, A.H. (2009) Genetic behaviour of some quantitative pea traits under southern Egypt conditions. Minufiya J. Agri. Res., 34 (4), 1601-1612.

El-Dakkak, A.A.A., Zayed, G.A. and Abd El-Hady, M.A.H. (2014) Improving productivity and earliness for pea by selection under sohag conditions. Egypt. J. Appl. Sci., 29 (11), 523-533.

El-Dakkak, A.A.A., Abd El-Hady, M.A. and Hussein, A.H. (2009) Gene action expression of some pea (Pisum sativum L.) traits as affected by seasonal variation of Southern Egypt conditions. Egypt J. Appl. Sci., 24 (4A), 241-256.

El-Murabaa, A.I., Waly, E.A., Abdel-Aal, S.A. and Zayed, G.A. (1988 a) Genetic studies in pea (Pisum sativum L.) I. Flowering, plant height and pod characters. Assiut J. Agri. Sci., 19 (2), 211-221.

El-Murabaa, A.I., Waly, E.A., Abdel-Aal, S.A. and Zayed, G.A. (1988 b) Genetic studies in pea (Pisum sativum L.). II. Yield and quality characteristics. Assiut J. Agri. Sci., 19 (2), 223-233.
El-Shaieny, A.A.H. and Ibrahim, E.M.A. (2017) Selection for productivity and earliness of (Pisum sativum L.) under late sowing. J. Amer. Sci., 13 (3), 167-172.

Ghobary, H.M. (2010) Study of Relationship between yield and some yield components in garden pea (Pisum sativum L.) by using correlation and path analysis. J. Agric. Res. KaferEl- Sheikh Univ., 36, 351-360.

Hamed, A.A. (2005) Genetic studies on powdery mildew resistance and some economic characters in some pea cultivars. Ph.D. Thesis, Fac. Agric., Cairo Univ., Egypt, 97 p.

Hasan, M.N.M., Abd El-Aty, Y.Y., Zayed, G.A. and Abd El Lah, H.S. (2010) Heterosis, correlation and gene action in some genotypes of pea (Pisum sativum L.). Minia $2^{\text {nd }}$ conf. Agric. Environ. Sci., $151-160$.

Kannoj, S.S. (2016) Morphological characterization and genetic analysis for yield and quality traits in field pea. M.Sc. Thesis, Jawa. Jabalpur, 102 p.

Katiyar, R.I (1994) Heterobeltiosis for morphological attributes in powdery mildew and rust resistance peas. Indian J. Pulses Res., 7 (1), 48-51.

Kumar, A. and Jain, B.P. (2003) Genetic variability in pea (Pisum sativum L.), J. Res. Birsa Agri. Univ., Indian, 15 (1), 55 -59.

Kumar, A.V.R. and Sharma, R.R. (2006) Character association studies in garden pea. Indian J. Hort., 63 (2), 185-187.

Kumar, B., Kumar, A., Singh, A.K. and Lavanya, G.R. (2013) Selection strategy for seed yield and maturity in field pea (Pisum sativum L. arvense). African J. Agri. Res., 8 (44), 5411-5415.

Kumaran, S.S., Natarajan, S. and Thamburaj, S. (1995) Genetic variability in peas (Pisum sativum L.). South Indian. Hort., 43 (112), 10-13 (C.F. Plant Breed. Abstr. 67, 1527).

Lejeune-Henaut, I., Fouilloux, G., Ambrose, M.J., Dumoulin, V. and Etévé G. (1992) Analysis of a 5 parent half diallel in dried pea (Pisum sativum L.). I. Seed yield heterosis. Agronomie, 12, 545-550.

Muhammed, S., Bacha, S., Arshad, M., Din, R. and Ghafoor, A. (2009) Genetic diversity for determining yield potential and selection criteria in Pisum sativum L., genetic resources. Pakistan Journal of Botany, 41(6), 2987-2993. 
Nassef, D.M.T. and El-Rawy, M.A. (2013) Analysis of gene effects controlling some traits in garden pea (Pisum Sativum L.). Austr. J. of Basic and Appl. Sci., 7(1), 537-542.

Nawab, N.N., Subhani, G.M., Mahboob, K., Shakil, Q. and Saeed, A. (2008) Genetic variability, correlation and pathanalysis studies in garden pea. Pakistan $J$. Agri. Res., 46 (4), 333-340.

Nosser, M. A. (2002) Genetic analysis of pea (Pisum Sativum L.) yield and its component by diallel crossing. Egypt. J. of applied. Sci, 22 (12) $312-$ 325 .

Pandey, V., Pant, T. and Das, S.D. (2006) Studies on heterosis and combining ability in pea. Indian $J$. of Hort., 63 (3), 338-340.

Sarawat, P., Stoddard, F.L., Marshall, D.R. and Ali, S. M. (1994) Heterosis for yield and related characters in pea. Euphytica, 80, 39-48.

Sharma, D.K., Adarsh, B. and Chaudhary, D.R. (1999) Studies on combiningability and gene action in pea (Pisum sativum L.).Indian J. Hill Far., 12, 32-36.

Shukla, A.K. (2015) Characterization and evaluation of field pea (Pisum sativum L.) genotypes for yield and quality attributing traits. M.Sc., Jawa, Jabalpur $89 \mathrm{p}$.

Sinha, S.K. and Khanna, R. (1975) Physiological, biochemical and genetic basis of heterosis. $A d v$. Agro., 27, 123-174.

Simakov, G.A. (1989) Collection of pea varieties in breeding for yield. Seleksia 1 Semenovdstvo (Moskva), 6, 11-13, (C.F. Plant Breed. Abstr. 60, 10667).

Singh, R.K. and Chaudhary, B.D. (1985) "Biometrical Methods in Quantitative Genetic Analysis", Kalyni Publishers, New Delhi, India, 318 pp.

Smith, H.H. (1952) Fixing Transgressive Vigor in Nicotiana Rustica. Iowa State College Press, Ames. Iowa. pp. 161-174.

Snedecor, G.W. and Cochran, W.G. (1982) "Statistical Methods", $7^{\text {th }}$ ed., Iowa State Univ. Press, Ames, $507 \mathrm{p}$.

Togay, N., Togay, Y., Yildirim, B. and Dogan, Y. (2008) Relationships between yield and some yield components in pea (Pisum sativumssp arvense L.) genotypes by using correlation and path analysis. African J. Biotec., 7 (23), 4285-4287. (http: \www. academicjournals.org $\backslash \mathrm{AJB}$ )
Wynne, J.C., Emery, D.A. and Rice, R.H. (1970) Combining ability estimation in Arachis hypogaea L. 11. Field performance of $\mathrm{F}_{1}$ hybrids. Crop Sci., 10 (6), 713-715.

Zayed, G.A., Amer, A.H. and Hassan, H.M. (1999a). Combining ability and path coefficient analysis in pea under southern Egypt conditions. Zagazig J. Agri. Res., 26 (3A), 611-621.

Zayed, G.A., Faris, F.S. and Amer, A.H. (1999b) Performance of some pea cultivars under the conditions of Upper Egypt. Egypt. J. Agric. Res., 77 (4), 1687-1704.

Zayed, G.A. (1998) Inheritance of some quantitative characters in peas. Egypt. J. Appl. Sci., 13 (3), 242253.

Zayed, G.A. and Faris, F.S. (1998) Estimates of heterosis and relative potence of gene set in pea (Pisum sativum L.) at Upper Egypt. Egypt. J. Appl. Sci., 13 (6), 187-200.

Zayed, G.A., Helal, F.A. and Farag, S.T. (2005) The genetic performance of some continuously variable characteristics of pea under different locations. Annals Agric. Sci., Moshtohor, 43, 337-346.

(Received 20/10/2018; accepted $12 / 12 / 2018$ 


\section{التحليل الوراثي فى بعض الهجن للمحصول ومكوناته والتبكير فى البسلة

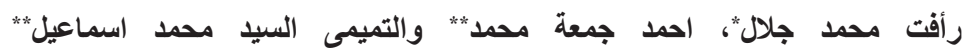

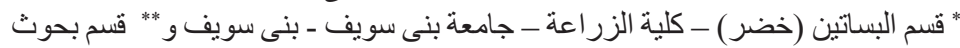

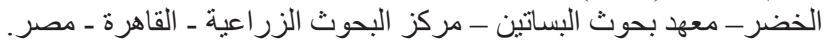

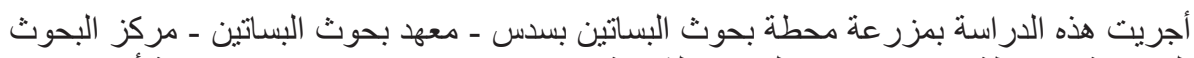

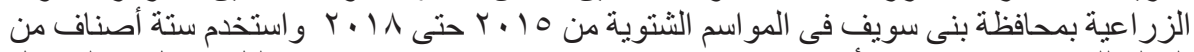

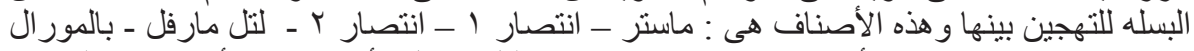

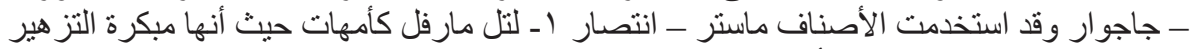

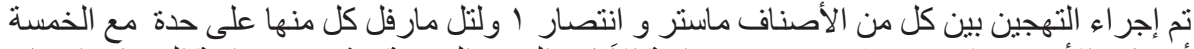

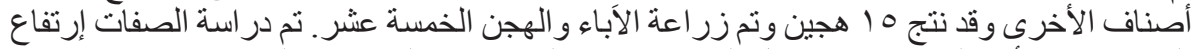

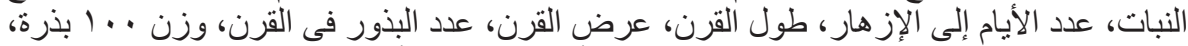

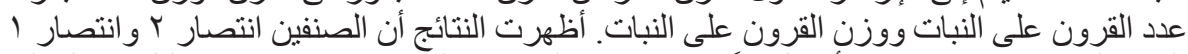

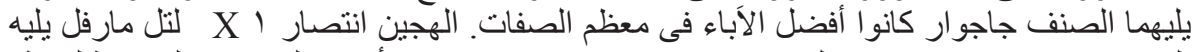

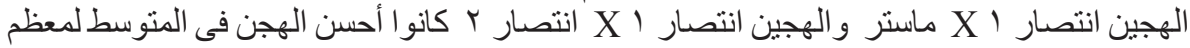

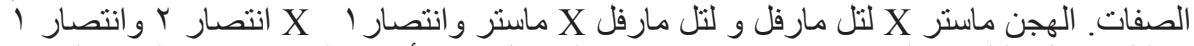

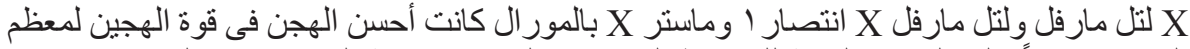

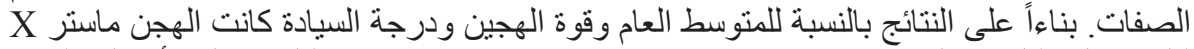

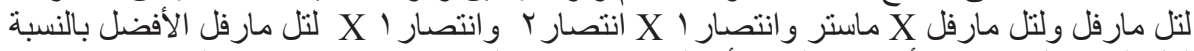

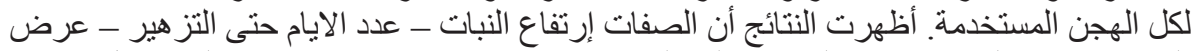

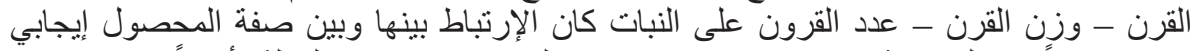

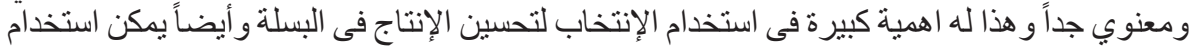
النتائج ألسابقة فى تحسين الإنتاجية والتبكير فى البسلة النيلة 